\title{
Minimally invasive carpal tunnel surgery in leprosy
}

\author{
José Marcos Pondé1, Clarissa Ramos², Lazaro Santos², \\ João Pedro Magalhaes², Ana Flavia Cavalcanti² \\ Department of Neurosciences and Mental Health Federal University of Bahia (UFBA), Salvador, BA, Brazil.
}

\begin{abstract}
Objective: Evaluate carpal tunnel release in leprosy. Methods: The authors operated upon 60 patients with median nerve involvement by leprosy between February 2008 and February 2012. The outpatients were under local anesthesia submitted to carpal tunnel release. Results: All the patients showed postoperative improvement in pain and sensation. Conclusion: The surgical approach is a cost effectiveness
\end{abstract} procedure adequate to developing countries.

\section{KEYWORDS}

Carpal tunnel syndrome, leprosy, median nerve.

\section{RESUMO}

Cirurgia minimamente invasiva do túnel do carpo em lepra

Objetivo: Avaliar a descompressão do túnel do carpo na lepra. Métodos: Os autores operaram 60 pacientes ambulatoriais com envolvimento do nervo mediano pela lepra, entre fevereiro de 2008 e fevereiro de 2012. Os pacientes foram submetidos a anestesia local e cirurgia de túnel do carpo. Resultados: Todos os pacientes experimentaram melhora no pós-operatório da sensibilidade e da dor. Conclusão: A abordagem cirúrgica é um procedimento de custo-efetividade satisfatório, adequada para países em desenvolvimento.

\section{PALAVRAS-CHAVE}

Síndrome do túnel carpal, hanseníase, nervo mediano.

\section{Introduction}

Carpal tunnel syndrome is a worldwide disease with different treatments. Each one offers advantages and risks. ${ }^{1-5}$ A different situation is anticipated when dealing with leprosy.

Leprosy is an endemic disease particularly in Brazil which represents the second most prevalent country supplanted only by India. The peripheral nerve involvement leads to physical deformities. ${ }^{6-8}$

Involvement of peripheral nerves in leprosy leads to tissue swelling and sometimes replacement by fibrosis. ${ }^{9-11}$

Median, ulnar, posterior tibial and fibular nerves are usually damaged.

Places of low body temperature are the best environmental for bacillus proliferation. ${ }^{7,8}$

Absence of improvement in pain following four months of treatment or abscess formation indicates surgical treatment. Otherwise severe peripheral nerve involvement also recommends surgery. ${ }^{12}$
The advent of endoscopy and microsurgery are very important in neurosurgery, although minimally invasive techniques and cost-effectiveness surgeries are welcome. This is particularly observed in developing countries daily involved with leprosy patients. ${ }^{13-16}$

Minimally invasive surgery seems appropriate to treat patients with carpal tunnel syndrome in leprosy disease.

The aim of surgery is release hypertrophied nerves. In this paper only median nerve compromise was assigned.

\section{Material and methods}

Altogether 341 subjects with compression neuropathy were submitted to 412 surgeries between February 2008 and February 2012 in the Hospital Colônia Dom Rodrigo de Menezes in Salvador, Bahia, Brazil of the

1 Chairman Division of Neurosurgery Department of Neurosciences and Mental Health Federal University of Bahia (UFBA), Salvador, BA, Brazil.

2 Student of Medicine, Bahiana School of Medicine and Public Health, Salvador, BA, Brazil. 
Public Health System. The mean age was 41,06 (between 8 and 87 years). One hundred and seventeen males and 98 females were enrolled. Ulnar was the most frequently involved nerve followed by the posterior tibial, median and fibular nerve. Sixty patients with median nerve compression in the wrist were submitted to transverse ligament release and external neurolysis. Patients operated on both sides were excluded.

Biopsy or bacilloscopy confirmed diagnosis in all cases.

Sixty-three percent of the patients were males and $37 \%$ females. The right side was involved in $43 \%$ of the times and the left in 57\%.

Pain was the most common complaint and the visual analogical scale was utilized taking reference of values between 0 and 10 (mean 7,53 points).

The sensation was quantified by means of the Semmens Weinberg monofilaments. The pinprick sensation varied between 0 to 5 . The 0 value is complete loss of sensibility and 5 normal sensation. The motor performance was measured in flexion of the thumb. The values vary between M0 and M5. M0 value is complete paralysis, M3 action against gravity and M5 normal strength.

Loss of sensation graded by the Semmens Weinberg method under 3 points (loss of protective sensation) or persistent pain remains despite three months of conservative management, indicates surgery.

\section{Surgical procedure}

The patient was positioned with the arm abducted without tourniquet under local anesthesia with lydocaine $2 \%$ and epinephrine.

The incision of $1,5 \mathrm{~cm}$ with blade $\mathrm{n}^{\circ} 15$ is made over the palmar region following the line comprising the fourth finger. Usually no coagulation is necessary. Two small retractors are placed to maintain the incision opened. With the knife blade the transverse carpal ligament is divided proximally and distally (Figure 1). A scissor interposed between the nerve and the sectioned transverse ligament release the synovial membrane from the ulnar side.

The median nerve is inspected and underwent external neurolysis (Figure 2).

The skin is closed with simple running suture following the subcutaneous closure. A bandage applied without compression. The skin suture removed with three weeks. No immobilization is required.

The surgery takes over 10 minutes.

\section{Statistics}

We used the T-Student test for comparisons between means.

Significant $\mathrm{p}$ values under 0,05 .

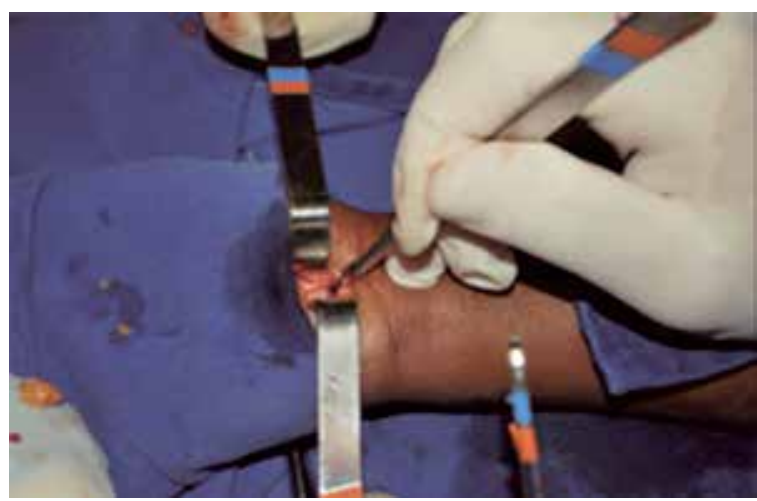

Figure 1 - Incision of the released flexor retinaculum.

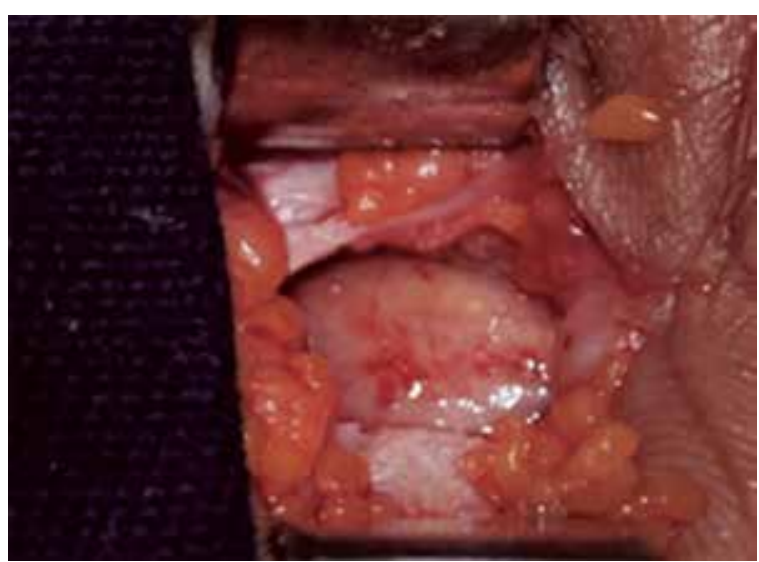

Figure 2-Median nerve.

\section{Results}

The pain improved in all the patients without major complications (Table 1). The analogical scale of pain showed a pre-operative middle value of 7,53 (0-10) and mean post-operative value of $2,15(p<0,001)$ (Table 1 ).

The mean time relapse between surgery and clinical improvement of sensation is three months. The mean pre-operative sensation value was 1,7 and post-operative $3,5(p<0,005)$ (Table 1) .

\begin{tabular}{lccccccc}
\hline \multicolumn{7}{c}{ Table 1 - Pain sensation and strengthem } \\
\hline \multicolumn{7}{c}{ PAIN } & \multicolumn{2}{c}{ Sensibility } & \multicolumn{2}{c}{ Strength } \\
& Pre & Pos & Pre & Pos & Pre & Pos & Patients \\
\hline Median R & 7.65 & 0.68 & 1.8 & 2.92 & 3.77 & 3.77 & 26 \\
Mediam L & 5.5 & 2.26 & 1.36 & 2.52 & 3.82 & 4.03 & 34 \\
Total & & & & & & & 60 \\
\hline
\end{tabular}

The evaluation of muscular strength showed a mean 3,77 preoperative and a mean 3,8 postoperative value (Table 1).

The single complication usually seen is dehiscence of operatory wound in that patients taking steroids in high doses. 


\section{Discussion}

Carpal tunnel syndrome is the most common entrapment lesion in the peripheral nerve system. ${ }^{1-5}$

The median nerve is often involved in leprosy disease allied to other sites as tibial, ulnar and fibular nerves. ${ }^{6-11}$

The pain, loss of sensation and trophic alterations culminate sometimes in clown hand. These finds differ of the classical carpal tunnel syndrome in which the right side is most frequently involved.

The incision doesn't cross the wrist affecting minimally the palmar fascia. There is a debate concerning palmar fascia section and weakness in hand muscles in those patients operated by open techniques. ${ }^{3,5}$ Until presently there is no evidence of superiority of endoscopic approach over the open techniques. ${ }^{3,5}$

The section of the transverse carpal ligament followed by external neurolysis very important in leprosy and cannot be realized by endoscopic technique. Endoscopic surgery implies primarily a blind dissection, introduction of cannulas sometimes very big to a naturally small channel. The hypertrophied median nerve offers a remarkable risk of damage a very important policy when dealing with a hypertrophic peripheral nerve disease instead external compression commonly seen in carpal tunnel syndrome.

In order to avoid complications a minor incision and a minor open surgery is mandatory to afford the best results.

\section{Conclusion}

The mini-open technique is a safe and easy method with minimal morbidity appropriate to developing countries with leprosy disease.

\section{Competing interests}

There is no conflict of interests in this publication.

\section{References}

1. Huang JH, Zager EL. Mini-open carpal tunnel decompression. Neurosurgery. 2004;54(2):397-9.
2. Wong KC, Hung LK, Ho PC, Wong JM. Carpal tunnel release. A prospective, randomised study of endoscopic versus limited-open methods. J Bone Joint Surg Br. 2003;85(6):863-8.

3. Benedetti VR, Sennwald G. Agee endoscopic decompression of the median nerve: prospective study with comparison to open decompression. Handchir Mikrochir Plast Chir. 1996;28(3):151-5.

4. Ahcan U, Arnez ZM, Bajrović F, Zorman P. Surgical technique to reduce scar discomfort after carpal tunnel surgery. J Hand Surg Am. 2002;27(5):821-7.

5. Brown RA, Gelberman RH, Seiler JG 3rd, Abrahamsson SO, Weiland AJ, Urbaniak JR, et al. Carpal tunnel release. A prospective, randomized assessment of open and endoscopic methods. J Bone Joint Surg Am. 1993;75(9):1265-75.

6. Husain S, Mishra B, Prakash V, Malaviya GN. Results of surgical decompression of ulnar nerve in leprosy. Acta Leprol. 1998;11(1):17-20.

7. Bryceson A, Pfaltzgraff RE. Complications due to nerve damage. In: Medicine in the tropics: leprosy. $3^{\text {rd }}$ ed. Edinburgh: Churchill Livingstone; 1990. p. 133-51.

8. Agrawal A, Pandit L, Dalal M, Shetty JP. Neurological manifestations of Hansen's disease and their management. Clin Neurol Neurosurg. 2005;107(6):445-54.

9. Junqueira LC, Montes GS, Neto EA, Barros C, TedscoMarchese AJ. The collagen of permanently damaged nerves in human leprosy. Int $\mathrm{J}$ Lepr Other Mycobact Dis. 1980;48(3):291-7.

10. Naafs B. Bangkok Workshop on Leprosy Research. Treatment of reactions and nerve damage. Int J Lepr Other Mycobact Dis. 1996;64(Suppl 4):S21-8.

11. Van Brakel WH. Peripheral neuropathy in leprosy and its consequences. Lepr Rev. 2000;71(Suppl):S146-53.

12. Sugumaran DS. Steroid therapy for paralytic deformities in leprosy. Int J Lepr Other Mycobact Dis. 1997;65(3):337-44.

13. Girdhar BK. Neuritic leprosy. Indian J Lepr. 1996;68(1):3542.

14. Croft RP, Nicholls PG, Steyerberg EW, Richardus $\mathrm{JH}$, Cairns W, Smith S. A clinical prediction rule for nerve-function impairment in leprosy patients. Lancet. 2000;355(9215):1603-6.

15. Husain S, Mishra B, Prakash V, Malaviya GN. Evaluation of results of surgical decompression of median nerve in leprosy in relation to sensory: motor functions. Acta Leprol. 1997;10(4):199-201.

16. Pandya NJ. Surgical decompression of nerves in leprosy. An attempt at prevention of deformities. A clinical, electrophysiologic, histopathologic and surgical study. Int J Lepr Other Mycobact Dis. 1978;46(1):47-55.

Correspondence address

José Marcos Pondé

Av. Paulo VI, 111, Pituba

41810-000 - Salvador, BA, Brasil

E-mail:vesalio@terra.com.br 